NOTE

\title{
Chytridiomycosis in endemic amphibians of the mountain tops of the Córdoba and San Luis ranges, Argentina
}

\author{
Julián N. Lescano ${ }^{1, *}$, Silvana Longo ${ }^{2}$, Gerardo Robledo \\ ${ }^{1}$ Instituto de Diversidad y Ecología Animal (CONICET-UNC), Centro de Zoología Aplicada, \\ Universidad Nacional de Córdoba, Rondeau 798, Córdoba 5000, Argentina \\ ${ }^{2}$ Laboratório de Micología, IMBIV (CONICET), Universidad Nacional de Córdoba, CC495, Córdoba 5000, Argentina
}

\begin{abstract}
Chytridiomycosis is a major threat to amphibian conservation. In Argentina, the pathogenic fungus Batrachochytrium dendrobatidis has been recorded in several localities, and recently, it was registered in amphibians inhabiting low-elevation areas of mountain environments in Córdoba and San Luis provinces. In the present study, we searched for B. dendrobatidis in endemic and non-endemic amphibians on the mountain tops of Córdoba and San Luis provinces. We collected dead amphibians in the upper vegetation belt of the mountains of Córdoba and San Luis. Using standard histological techniques, the presence of fungal infection was confirmed in 5 species. Three of these species are endemic to the mountain tops of both provinces. Although there are no reported population declines in amphibians in these mountains, the presence of $B$. dendrobatidis in endemic species highlights the need for long-term monitoring plans in the area.
\end{abstract}

KEY WORDS: Batrachochytrium dendrobatidis $\cdot$ Argentina $\cdot$ Anurans $\cdot$ Mountains

\section{INTRODUCTION}

Amphibians are undergoing an unprecedented conservation crisis (Houlahan et al. 2000, Stuart et al. 2004). Several factors are related to this global phenomenon, including emergent diseases such as chytridiomycosis, which are a major threat to amphibian conservation (Collins \& Storfer 2003, Daszak et al. 2003, Skerratt et al. 2007). Chytridiomycosis is caused by the fungal pathogen Batrachochytrium dendrobatidis $(B d)$ and it has been proposed as the proximal cause of several declines of amphibian populations around the world (Berger et al. 1998, Bosch et al. 2001, Rohr \& Raffel 2010). The origin and spread of this emergent disease is still unclear, and 2 contrasting hypotheses are being discussed (Rachowicz et al. 2005). The first has been called the 'novel pathogen hypothesis' or 'spreading pathogen hypothesis' (Rachowicz et al. 2005, Skerratt et al. 2007) and postulates that the introduction and spread of $B d$ among naive populations of frogs has caused the emergence of chytridiomycosis worldwide. The second hypothesis, the 'emerging endemic hypothesis', postulates that $B d$ was already a widespread pathogen that has become highly pathogenic and virulent because of abnormal environmental changes (e.g. climate change, pollution) (Rachowicz et al. 2005). Although there is no consensus, there is more evidence in favor of the first hypothesis (Skerratt et al. 2007).

In Argentina, $B d$ has been recorded in eastern (Herrera et al. 2005), northwestern (Barrionuevo \& Mangione 2006), southern (Fox et al. 2006), and northeastern (Arellano et al. 2010) regions of the 
country, and recently it was recorded in amphibians inhabiting low-elevation areas (around $800 \mathrm{~m}$ above sea level [a.s.l.]) of mountain environments in central Argentina in the Córdoba and San Luis provinces (Ghirardi et al. 2010, Gutierrez et al. 2010).

The tops of the mountain systems Sierras Grandes, Sierras de Comechingones, and Sierras de San Luis in the Córdoba and San Luis provinces have a high degree of geographic isolation (Fig. 1A) and therefore have several endemic species of plants (Vischi et al. 2004), birds (Nores 1995), and fungi (Robledo et al. 2003, 2006, Robledo \& Renison 2010). Seven species of amphibians inhabit the mountain tops (between 1800 and $2800 \mathrm{~m}$ a.s.l.) of Córdoba and San Luis, and 4 of them are endemic to these environments (Cei 1972, 1980, di Tada \& Bucher 1996, Valleti et al. 2009, Verga et al. 2012). About $400 \mathrm{yr}$ ago, domestic animals, such as cattle, sheep, and horses, were introduced into the Córdoba mountains (García et al. 2008). Long-term livestock grazing combined with frequent anthropogenic fires has led to the degradation, fragmentation, and decline of habitats, such as tussock grasslands and Polylepis australis woodlands (Cingolani et al. 2004, Renison et al. 2006). Due to these human factors, the endemic amphibians of the mountains tops of Córdoba and San Luis are listed as Near Threatened in the IUCN Red List of Threatened Species (Lavilla \& di Tada 2004a,b, Lavilla et al. 2004) and as Vulnerable and Threatened in Argentina (Vaira et al. 2012).

It has been suggested that the decline in amphibian populations related to epizootics of chytridiomycosis is most common at higher elevations (Alford et al. 2001, Young et al. 2001), and that the most susceptible species have restricted altitudinal ranges (Lips et al. 2006, Kriger \& Hero 2007). Aiming to explore the presence of pathogenic fungi in amphibians of the mountain tops of Córdoba and San Luis provinces, Argentina, we searched for $B d$ in the amphibians of the area. Here we present the first record of the disease in threatened and endemic amphibians of the mountain tops of Córdoba and San Luis.

\section{MATERIALS AND METHODS}

\section{Study area}

The study was conducted in the upper vegetation belt of the mountain system of the Sierras Grandes in Córdoba province and at one locality of the Sierras de San Luis in San Luis province. The Sierras
Grandes continue into the mountain range called Comechingones, located in the provinces of Córdoba and San Luis (Fig. 1). The area comprises different landscapes, including valley bottoms and ravines, plateaus with different degrees of dissection, rocky hilly uplands, and steep escarpments (Cabido et al. 1987). Vegetation consists of a mosaic of tussock grasslands, grazing lawns, granite outcrops, Polylepis australis woodlands, and eroded areas with exposed rock surfaces (Cabido 1985, Cingolani et al. $2003,2004)$. The climate is typical of mountain areas, with mean annual winter and summer temperatures of 5 and $11.4^{\circ} \mathrm{C}$, respectively. Precipitation is concen-

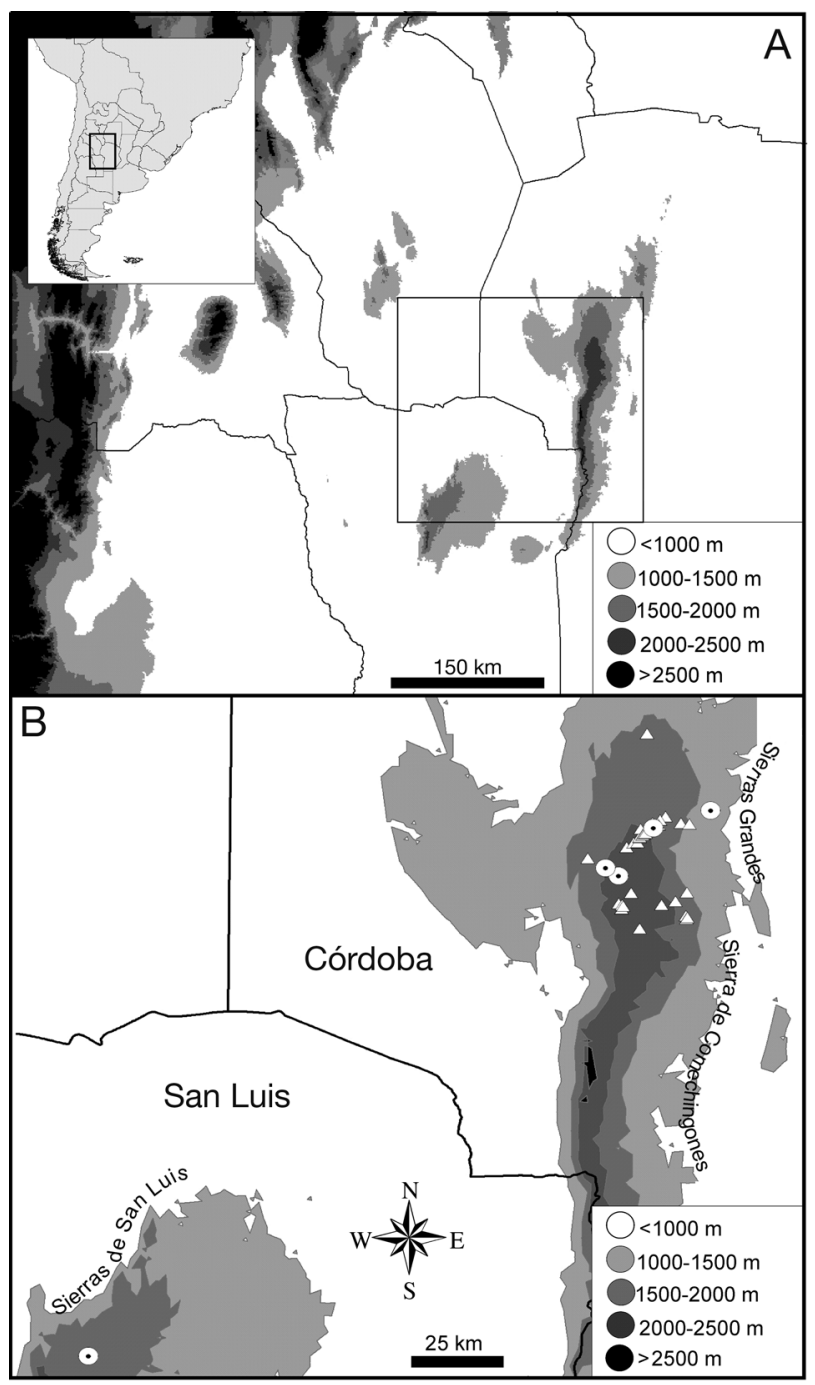

Fig. 1. (A) Location of the mountains of Córdoba and San Luis (area within the box) in central Argentina (inset: South America). Note the degree of isolation of these mountain ranges. (B) Study area and sampling sites. Surveyed streams and ponds $(\Delta)$ and localities with the presence of infected frogs $(\odot)$ are indicated 
trated between November and March and reaches an annual mean of $850 \mathrm{~mm}$ (Cabido 1985).

\section{Sampling}

Amphibian samples were obtained in stretches of $500 \mathrm{~m}$ length in 30 permanent streams. We also sampled 5 small temporary ponds (between 25 and $100 \mathrm{~m}^{2}$ ) (Fig. 1B). Surveys were conducted over $3 \mathrm{yr}$ in months of anuran activity (August to April, 2007 to 2010). Twenty-seven stretches were located in the upper vegetation belt of the Sierras Grandes (between 1800 and $2400 \mathrm{~m}$ a.s.l.), and 3 were located in streams at lower altitudes (between 1200 and $1650 \mathrm{~m}$ a.s.l.). All ponds were located in the upper vegetation belt of the mountain areas. At each stream stretch or pond, we recorded dead amphibians, in both diurnal and nocturnal surveys.

Dead individuals collected were immediately fixed in $10 \%$ neutral formalin. Abdominal and hind limb ventral skin patches (approximately $5 \times 10 \mathrm{~mm}$ ) were excised from the anurans, stored in $70 \%$ ethanol, and dehydrated to be embedded in paraffin. Then, tissues were sectioned at $5 \mu \mathrm{m}$ thickness with a microtome for histology, and stained with hematoxylin and eosin (H\&E). With a compound light microscope, we searched for spores and sporangia in the corneous epithelium of the tissue samples, following Berger et al. (2000) and Pessier et al. (1999). In some cases, periodic acid Schiff (PAS) staining was employed to highlight morphologic features of $B d$ and then confirm the diagnosis.

The Achala toad Rhinella achalensis was not found during the first 3 yr of surveys (2007 to 2009). In order to obtain tissue of this species, we extracted samples of 5 previously collected specimens kept at Cátedra de Ecología, Universidad Nacional de Rio Cuarto, Argentina. Four of these specimens had been collected at Sierras Grandes (Córdoba province) and one at La Carolina, Sierras de San Luis (San Luis province). Finally during the surveys of 2010, we detected one population of Achala toads, and one juvenile individual belonging to this population was found dead.

All specimens collected in the present study are kept in the amphibian collection of the Centro de Zoología Aplicada (Universidad Nacional de Córdoba, Argentina).

\section{RESULTS}

Sixteen individuals belonging to 6 species were found dead in 7 streams and 1 pond surveyed (Table 1). We confirmed the presence of chytrid fungal infection in 5 individuals belonging to 5 of the 6 species surveyed. Infected individuals were collected at 4 different streams of Sierras Grandes (Table 1, Figs. 1B \& 2A). In addition, one of the individuals analyzed from the Universidad Nacional de Rio Cuarto collection, from La Carolina, San

Table 1. Individuals analyzed to assess the presence of Batrachochytrium dendrobatidis (Bd). Numbers in parentheses indicate number of individuals (if $>1$ ) analyzed at each locality in the same year. Individuals with confirmed presence of $B d$ are marked in bold. CZAa: collection of amphibians of the Centro de Zoología Aplicada, Universidad Nacional de Córdoba, Argentina.

UNRC-ECO: collection of Cátedra de Ecología, Universidad Nacional de Río Cuarto, Argentina. nd: no data available

\begin{tabular}{|c|c|c|c|c|}
\hline Species & Locality & Coordinates & $\begin{array}{c}\text { Year of } \\
\text { collection }\end{array}$ & Collection no. \\
\hline Hypsiboas cordobae & Río Yuspe & $31^{\circ} 22^{\prime} 48.60^{\prime \prime} \mathrm{S}, 64^{\circ} 46^{\prime} 22.02^{\prime \prime} \mathrm{W}$ & 2008 & CZAa0009 \\
\hline H. cordobae & Los Gigantes & $31^{\circ} 24^{\prime} 4.06^{\prime \prime} \mathrm{S}, 64^{\circ} 47^{\prime} 14.40^{\prime \prime} \mathrm{W}$ & 2009 & CZAa0141 \\
\hline H. cordobae & Copina & $31^{\circ} 34^{\prime} 15.13^{\prime \prime} \mathrm{S}, 64^{\circ} 42^{\prime} 33.74^{\prime \prime} \mathrm{W}$ & 2008 & CZAa0146 \\
\hline Melanophryniscus stelzneri & Los Gigantes & $31^{\circ} 23^{\prime} 35.62^{\prime \prime} \mathrm{S}, 64^{\circ} 46^{\prime} 32.52^{\prime \prime} \mathrm{W}$ & 2010 & CZAa0148 \\
\hline M. stelzneri & Los Gigantes & $31^{\circ} 23^{\prime} 35.62^{\prime \prime} \mathrm{S}, 64^{\circ} 46^{\prime} 32.52^{\prime \prime} \mathrm{W}$ & 2007 & CZAa0014 \\
\hline Odontophrynus achalensis (2) & Río Yuspe & $31^{\circ} 22^{\prime} 48.60^{\prime \prime} \mathrm{S}, 64^{\circ} 46^{\prime} 22.02^{\prime \prime} \mathrm{W}$ & 2008 & CZAa0007, CZAa0008 \\
\hline O. achalensis (2) & Los Gigantes & $31^{\circ} 24^{\prime} 4.06^{\prime \prime} \mathrm{S}, 64^{\circ} 47^{\prime} 14.40^{\prime \prime} \mathrm{W}$ & 2009 & CZAa0142, CZAa0143 \\
\hline O. achalensis & La Ventana & $31^{\circ} 3139.74^{\prime \prime} \mathrm{S}, 64^{\circ} 525.64^{\prime \prime} \mathrm{W}$ & 2009 & CZAa0147 \\
\hline O. achalensis & El Volcán & $31^{\circ} 30^{\prime} 24.14^{\prime \prime} \mathrm{S}, 64^{\circ} 53^{\prime} 54.63^{\prime \prime} \mathrm{W}$ & 2010 & CZAa0155 \\
\hline Pleurodema kriegi & El Volcán & $31^{\circ} 30^{\prime} 24.14^{\prime \prime} \mathrm{S}, 64^{\circ} 53^{\prime} 54.63^{\prime \prime} \mathrm{W}$ & 2010 & CZAa0154 \\
\hline P. kriegi & Cerro blanco & $31^{\circ} 2115.41^{\prime \prime} \mathrm{S}, 64^{\circ} 3914.37^{\prime \prime} \mathrm{W}$ & 2008 & CZAa0002 \\
\hline P. kriegi & La Ventana & $31^{\circ} 31^{\prime} 39.74^{\prime \prime} \mathrm{S}, 64^{\circ} 52^{\prime} 5.64^{\prime \prime} \mathrm{W}$ & 2010 & CZAa0154 \\
\hline Rhinella arenarum & Los Gigantes & $31^{\circ} 244.06^{\prime \prime} \mathrm{S}, 64^{\circ} 4714.40^{\prime \prime} \mathrm{W}$ & 2009 & CZAa0144 \\
\hline R. achalensis & El Volcán & $31^{\circ} 3024.14 " \mathrm{~S}, 64^{\circ} 5354.63 " \mathrm{~W}$ & 2010 & CZAa0164 \\
\hline R. achalensis (5) & Pampa de Achala & nd & 1995 & UNRC-ECO667 to 671 \\
\hline R. achalensis & La Carolina & nd & 1999 & UNRC-ECO644 \\
\hline
\end{tabular}




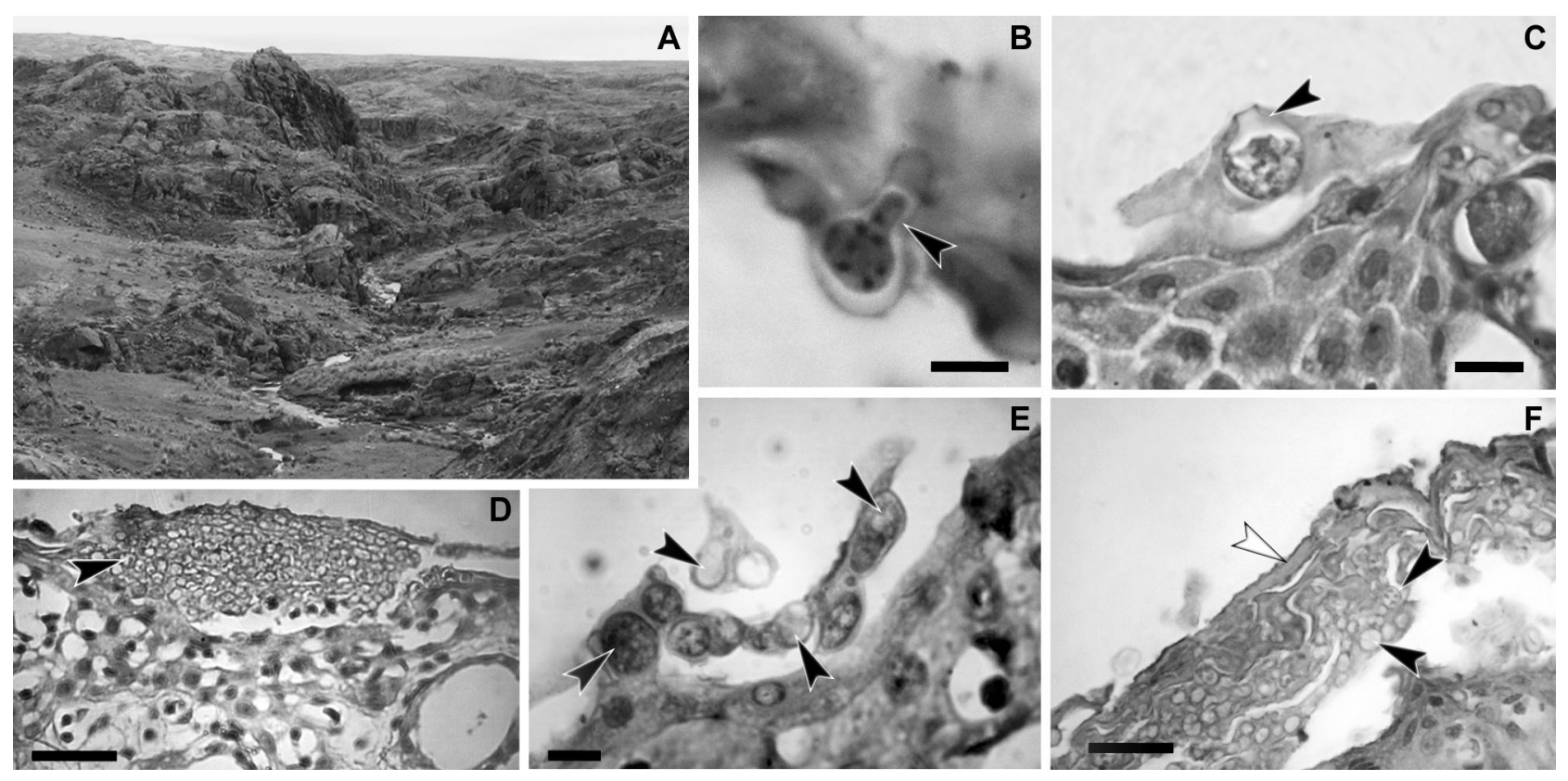

Fig. 2. (A) A stream in the upper vegetation belt of Sierras Grandes. (B) Zoosporangium with a discharge papilla (arrowhead) in the skin of Hypsiboas cordobae; scalebar $=10 \mu \mathrm{m}$. (C) Zoosporangia with a discharge papilla (arrowhead) in the skin of the endemic amphibian Odontophrynus achalensis; scalebar $=10 \mu \mathrm{m}$. (D) Severe epidermal hyperplasia and moderate hyperkeratosis in the skin of the toad Rhinella arenarum. Note the large numbers of Batrachochytrium dendrobatidis (Bd) zoosporangia (arrowhead) in the stratum corneum; scalebar $=50 \mu \mathrm{m}$. (E) Zoosporangia at different developmental stages (arrowheads) in the skin of the endemic frog Pleurodema kriegi; scalebar $=10 \mu \mathrm{m}$. (F) Different developmental stages of $B d$ in the skin of the endemic toad $R$. achalensis. Note the large numbers of $B d$ zoosporangia (black arrowheads) at different developmental stages in the stratum corneum and the severe hyperkeratosis of the skin (white arrowhead); scalebar $=50 \mu \mathrm{m}$

Luis, was infected with $B d$ (Table 1, Fig. 1B). Confirmed infected specimens belong to species with wide distribution ranges (Rhinella arenarum), as well as endemic species of the mountains of Córdoba and San Luis (Hypsiboas cordobae), and 3 endemic species of the mountain tops of Córdoba and San Luis ( $R$. achalensis, Pleurodema kriegi, Odontophrynus achalensis). There were no signs of infection in the 2 Melanophryniscus stelzneri individuals collected.

Zoosporangia at different developmental stages were observed in the stratum corneum of infected individuals (Fig. 2B-F). We observed zoosporangia with discharge papillae to release the zoospores oriented toward the skin surface in Hypsiboas cordobae and Odontophrynus achalensis (Fig. 2B,C). Zoosporangia containing rounded basophilic zoospores were observed in these species. In individuals with an advanced stage of disease, the presence of empty zoosporangia was detected (Fig. 2D-F). Moreover, some colonial thalli were observed in the skin of Pleurodema kriegi and Rhinella arenarum.

Histological analyses also revealed different skin changes in infected individuals. Some species had mild epidermal hyperplasia (Hypsiboas cordobae), while others (Rhinella arenarum and $R$. achalensis) had severe epidermal hyperplasia and moderate to severe hyperkeratosis (Fig. 2D,F).

The furthest apart sites with infected amphibians were at a straight-line distance of $252 \mathrm{~km}$ (Fig. 1B). The average altitude of sites with the presence of $B d$ was $1805 \mathrm{~m}$ a.s.l. (range: 1250 to $2200 \mathrm{~m}$ a.s.l.).

\section{DISCUSSION}

Threats such as disease, introduced predators, or habitat destruction are more likely to cause declines in an isolated, endemic, or rare species than in a widespread species with numerous subpopulations (Davies et al. 2000, Green 2003). Our results show that most amphibian species inhabiting the mountain tops of Córdoba and San Luis are infected with $B d$. Because complete necropsy examination could not be performed, the possibility that the death of these frogs was due to a factor other than $B d$ infection could not be excluded. However, the magnitude of $B d$ infection and the severity of associated epidermal hyperplasia and hyperkeratosis in Rhinella spp. suggests that chytridiomycosis was the likely cause of 
death in these species. Since the susceptibility of frogs of this area to fungal infection is still unknown, we highlight the presence of $B d$ as a potential major threat for the amphibian assemblages of this isolated mountain system, in addition to the threats already mentioned by Lavilla \& di Tada $(2004 \mathrm{a}, \mathrm{b})$ and Lavilla et al. (2004).

Previous records of $B d$ in Córdoba and San Luis were made at lower altitudes (near $800 \mathrm{~m}$ a.s.l.) and in widely distributed species (Hypsiboas cordobae, Odontophrynus occidentalis, Leptodactylus gracilis, L. latrans) (Ghirardi et al. 2010, Gutierrez et al. 2010). The observed distance between more distant points with infected amphibians recorded in the present study (Fig. 1B) in addition to the previous records suggests that $B d$ may be widely distributed over the mountains of Córdoba and San Luis, and that the presence of fungal infection in adjacent areas would also be expected, since the headwaters of numerous rivers and streams that run through other ecoregions, such as the Pampas Grasslands and Chaco dry forests, originate in these mountains. Moreover, our results not only show that the fungal pathogen is widely distributed on the tops of the mountains of Córdoba and San Luis but also represents the first record of the disease in endemic amphibians of the area (Rhinella achalensis, Odontophrynus achalensis, and Pleurodema kriegi).

Even though there are no studies demonstrating declines in amphibian populations of the mountains of Córdoba and San Luis provinces, personal observations of the authors during the last 5 yr suggest that some specific populations of the threatened and endemic toad Rhinella achalensis have declined (Lescano 2012, J. N. Lescano \& S. Longo unpubl. data). Although there is no evidence to link these apparent declines with $B d$ infection, the presence of the fungal disease in the mountain tops of Córdoba and San Luis shows the urgent need to start a longterm monitoring plan to evaluate population trends in endemic amphibians of the area.

Acknowledgements. We thank Ismael di Tada, Adolfo Martino, and Julián Valetti from the Universidad Nacional de Rio Cuarto for permission and help in examining and obtaining tissue from specimens in the Cátedra de Ecología collection. We are grateful to 3 anonymous reviewers, who made valuable comments and helped improve the manuscript; Javier Nori for help with the figures; Cecilia Garcia for English corrections; and Ismael di Tada for valuable information shared on Rhinella achalensis populations. J.N.L. and S.L. are $\mathrm{PhD}$ fellows and G.R. is assistant researcher at the National Research Council of Argentina (CONICET). J.N.L. and S.L. are doctoral students at the Universidad Nacional de Córdoba.

\section{LITERATURE CITED}

Alford RA, Dixon PM, Pechmann JHK (2001) Global amphibian population declines. Nature 412:499-500

Arellano ML, Ferraro DP, Steciow MM, Lavilla EO (2010) Infection by the chytrid fungus Batrachochytrium dendrobatidis in the yellow belly frog (Elachistocleis bicolor) from Argentina. Herpetol J 19:217-220

> Barrionuevo S, Mangione S (2006) Chytridiomycosis in two species of Telmatobius (Anura: Leptodactylidae) from Argentina. Dis Aquat Org 73:171-174

> Berger L, Speare R, Daszak P, Green DE and others (1998) Chytridiomycosis causes amphibian mortality associated with population declines in the rain forests of Australia and Central America. Proc Natl Acad Sci USA 95:9031-9036

Berger L, Speare R, Kent A (2000) Diagnosis of chytridiomycosis of amphibians by histological examination. Zoo's Print J 15:184-190

Bosch J, Martinez-Solano I, García-París M (2001) Evidence of a chytrid fungus infection involved in the decline of the common midwife toad (Alytes obstetricans) in protected areas of central Spain. Biol Conserv 97:331-337

Cabido M (1985) Las comunidades vegetales de la Pampa de Achala, Sierras de Córdoba, Argentina. Doc Phytosociol 9:431-443

Cabido M, Breimer R, Vega G (1987) Plant communities and associated soil types in a high plateau of the Córdoba mountains, central Argentina. Mt Res Dev 7:25-42

Cei JM (1972) Segregación corológica y procesos de especiación por aislamiento en anfibios de la Pampa de Achala, Córdoba. Acta Zool Lillo 29:233-246

Cei JM (1980) Amphibians of Argentina. Monit Zool Ital Monogr 2:1-609

- Cingolani AM, Cabido M, Renison D, Solís Neffa V (2003) Combined effects of environment and grazing on vegetation structure in Argentine granite grasslands. J Veg Sci 14:223-232

> Cingolani AM, Renison D, Zak M, Cabido M (2004) Mapping vegetation in a heterogeneous mountain using Landsat data: an alternative method to define and classify land-cover units. Remote Sens Environ 92:84-97

Collins JP, Storfer A (2003) Global amphibian declines: sorting the hypotheses. Divers Distrib 9:89-98

Daszak P, Cunningham AA, Hyatt AD (2003) Infectious disease and amphibian population declines. Divers Distrib 9:141-150

- Davies KF, Margules CR, Lawrence JF (2000) Which traits of species predict population declines in experimental forest fragments? Ecology 81:1450-1461

di Tada IE, Bucher EH (1996) Biodiversidad de la Provincia de Córdoba-fauna. Ediciones Universidad Nacional de Río Cuarto, Río Cuarto

$>$ Fox SF, Greer AL, Torres-Cervantes R, Collins JP (2006) First case of ranavirus-associated morbidity and mortality in natural populations of the South American frog Atelognathus patagonicus. Dis Aquat Org 72:87-92

García C, Reninson D, Cingolani A, Fernández-Juricic E (2008) Avifaunal changes as a consequence of largescale livestock exclusion in the mountains of Central Argentina. J Appl Ecol 45:1-10

Ghirardi R, Lescano JN, Longo MS, Robledo G, Steciow M, Perotti MG (2010) Batrachochytrium dendrobatidis in Argentina: first record in Leptodactylus gracilis and another record in Leptodactylus ocellatus. Herpetol Rev 40:175-176 
Green DM (2003) The ecology of extinction: population fluctuation and decline in amphibians. Biol Conserv 111: 331-343

Gutierrez FR, Arellano ML, Moreno LE, Natale GS (2010) Batrachochytrium dendrobatidis in Argentina: first record of infection in Hypsiboas cordobae and Odontophrynus occidentalis tadpoles, in San Luis Province, Argentina. Herpetol Rev 34:323-325

Herrera RA, Steciow MM, Natale GS (2005) Chytrid fungus parasitizing the wild amphibian Leptodactylus ocellatus (Anura: Leptodactylidae) in Argentina. Dis Aquat Org 64:247-252

Houlahan JE, Findlay CS, Schmidt BR (2000) Quantitative evidence for global amphibian population declines. Nature 404:752-755

Kriger KM, Hero JM (2007) The chytrid fungus Batrachochytrium dendrobatidis is non-randomly distributed across amphibian breeding habitats. Divers Distrib 13: 781-788

Lavilla EO, di Tada IE (2004a) Odontophrynus achalensis. In: IUCN Red List of Threatened Species. www.iucn redlist.org (accessed 2 Feb 2012)

Lavilla EO, di Tada IE (2004b) Pleurodema kriegi. In: IUCN Red List of Threatened Species. www.iucnredlist.org (accessed 2 Feb 2012)

Lavilla EO, di Tada IE, Reading CJ (2004) Rhinella achalensis. In: IUCN Red List of Threatened Species. www.iucn redlist.org (accessed 2 Feb 2012)

Lescano JN (2012) Rhinella achalensis (Cei, 1972). Sapo de Achala. Cuad Herpetol 26 (in press)

Lips KR, Brem F, Brenes R, Reeve JD and others (2006) Emerging infectious disease and the loss of biodiversity in a Neotropical amphibian community. Proc Natl Acad Sci USA 103:3165-3170

Nores M (1995) Insular biogeography of birds on mountaintops in north western Argentina. J Biogeogr 22:61-70

Pessier AP, Nichols DK, Longcore JC, Fuller MS (1999) Cutaneous chytridiomycosis in poison dart frogs (Dendrobates spp.) and White's tree frogs (Litoria caerulea). J Vet Diagn Invest 11:194-199

Rachowicz LJ, Hero JM, Alford RA, Taylor JW and others (2005) The novel and endemic pathogene hypotheses. Competing explanations for the origin of emerging infectious diseases of wildlife. Conserv Biol 19:1441-1448

Editorial responsibility: John Austin, Oldendorf/Luhe, Germany
Renison D, Hensen I, Suarez R, Cingolani AM (2006) Cover and growth habit of Polylepis woodlands and shrublands in the mountains of central Argentina: human or environmental influence? J Biogeogr 33:876-887

Robledo G, Renison D (2010) Wood-decaying polypores in the mountains of Central Argentina in relation to Polylepis forest structure and altitude. Fungal Ecol 3: 178-184

Robledo G, Urcelay C, Rajchenberg M (2003) New species causing decay on living Polylepis australis in Córdoba, central Argentina. Mycologia 95:347-353

> Robledo G, Urcelay C, Domínguez L, Rajchenberg M (2006) Taxonomy, ecology and biogeography of Polypores (Basidiomycetes) from Argentinian Polylepis woodlands. Can J Bot 84:1561-1572

Rohr JR, Raffel TR (2010) Linking global climate and temperature variability to widespread amphibian declines putatively caused by disease. Proc Natl Acad Sci USA 107:8269-8274

Skerratt LF, Berger L, Speare R, Cashins S and others (2007) Spread of chytridiomycosis has caused the rapid global decline and extinction of frogs. EcoHealth 4:125-134

Stuart SN, Chanson JS, Cox NA, Young BE, Rodrigues ASL, Fischman DL, Waller RW (2004) Status and trends of amphibian declines and extinctions worldwide. Science 306:1783-1786

Vaira M, Akmentins M, Attademo A, Baldo D and others (2012) Categorización del estado de conservación de los anfibios de la República Argentina. Cuad Herpetol 26 (in press)

Valleti J, Salas NE, Martino AL (2009) A new polyploid species of Pleurodema (Anura: Leiuperidae) from Sierra de Comechingones, Córdoba, Argentina and redescription of Pleurodema kriegi (Müller, 1926). Zootaxa 2073:1-21

> Verga EG, Leynaud GC, Lescano JN, Bellis LM (2012) Is livestock grazing compatible with amphibian diversity in the High Mountains of Córdoba, Argentina? Eur J Wildl Res 58:823-832

Vischi N, Natale E, Villamil C (2004) Six endemic plant species from central Argentina: an evaluation of their conservation status. Biodiversity Conserv 13:997-1008

> Young BE, Lips KR, Reaser JK, Ibanez R and others (2001) Population declines and priorities for amphibian conservation in Latin America. Conserv Biol 15:1213-1223

Submitted: March 8, 2012; Accepted: November 1, 2012 Proofs received from author(s): December 20, 2012 